\title{
KASZUBSKI DYSKURS NARODOWOŚCIOWY - SPOJRZENIE ANTROPOLOGICZNE
}

\author{
PROBLEMY Z "NARODEM"
}

C elem tego tekstu nie jest dowiedzenie, czy Kaszubi są narodem czy nie są, a w związku z tym, czy należy im się status mniejszości narodowej lub etnicznej, o który w 2013 roku rozpoczęa starania niewielka grupa Kaszubów zorganizowanych w Stowarzyszeniu Osób Narodowości Kaszubskiej „Kaszëbskô Jednota". Celem tego artykułu jest przedstawienie obecnie toczącego się na Kaszubach dyskursu narodowego w szerokiej perspektywie. Jednak początkowe zastrzeżenie jest tym ważniejsze, że właśnie wokół problemu konsekwencji politycznych użycia terminu "naród" koncentruje się w tej chwili na Kaszubach dyskurs narodowościowy.

Do podjęcia delikatnego tematu analizy kaszubskich dyskursów narodowościowych skłoniła mnie obserwacja działań i dyskusji podejmowanych w ostatnich latach na Kaszubach, z której wynika, że kaszubska kwestia narodowa stanowi obecnie gorący temat, który łączy i dzieli zaangażowane środowiska kaszubskie. Znamienne jest, że wszelkie wzmianki o kwestii narodowej prowokują burzę w każdym środowisku kaszubskich działaczy, zarówno wśród ludzi bardzo młodych, zaczynających dopiero angażować się w kaszubskie sprawy, jak i wśród należących do najstarszego pokolenia kaszubskich aktywistów. Dyskusje te jednak rzadko są konstruktywne. Mają często formę słownej przepychanki i zarzutów ad personam kierowanych do
Dr Nicole DOLOWY-RYBIŃSKA jest adiunktem w Instytucie Slawistyki PAN. nicoledolowy@gmail.com

\section{......}

* Projekt został sfinansowany ze środków Narodowego Centrum Nauki przyznanych na podstawie decyzji numer DEC-2011/01/D/HS2/02085. 
oponentów. Trudno jednak się dziwić, wszak dyskusja ta nie dotyczy jedynie kwestii politycznych, ale samoświadomości, tożsamości budowanej latami przez wspólnotę, jej często bardzo trudnych - przeżyć zakodowanych w pamięci zbiorowej, wreszcie odczuć jednostek, od których wymaga się deklaracji tożsamościowej. Tymczasem jednoznaczna identyfikacja na terenach pogranicznych, do których Kaszuby z pewnością można zaliczyć, jest problematyczna. Taka dokonana może być jedynie przez osoby świadomie podejmujące wybór, jak chcą się określić nie tylko wobec swoich, ale też wobec ludzi z zewnątrz.

Stanisław Ossowski twierdzit, że etniczność należy do zakresu świadomości kulturowej, zaś narodowość do zakresu świadomości politycznej [Ossowski 1967: 251-252]. Jeśli przyjąć taką perspektywę, okazuje się, że kaszubska kwestia narodowa wychodzi poza ramy zbiorowej tożsamości, stając się projektem politycznym. Ten z kolei zawsze uwikłany jest w ideologie. O tym, jaki dana grupa ma status w danym państwie (mniejszość etniczna/narodowa/grupa posługująca się językiem regionalnym itd.) decyduje wszak decyzja polityczna podejmowana przez grupę dominującą. Na podobnych przesłankach nadawana jest etykieta narodu. Dlatego też jeszcze raz podkreślam, że nie chcę zabierać głosu w dyskusji dotyczącej istnienia (bądź nie) narodu kaszubskiego - jest to bowiem dyskusja polityczna, nie naukowa.

Istnieje wiele definicji narodu i koncepcji nacjonalizmu, które nie tylko inaczej traktują zbiorowości, od czego innego je wywodzą i inne stawiają im cele, ale też niekiedy nawzajem się wykluczają. Dowodzenie istnienia bądź nieistnienia kaszubskiego narodu oznaczatoby konieczność przyjęcia jednej definicji i stopniowej analizy kolejnych jej aspektów i poziomów, podliczenia argumentów „za” i „przeciw” i jednoznacznego określenia statusu badanej grupy. Każda z definicji narodu: czy to pojmowanego jako byt obiektywny, istniejący na podstawie pewnych konkretnych cech, czy pojmowanego jako byt subiektywny, istniejący dlatego, że pewna grupa osób sama się za naród uważa, jest niewystarczająca i upraszczająca, gdyż - jak określili to Burszta i Jaskułowski: „naród nie jest czymś, co istnieje niezależnie od naszego postrzegania świata, nie jest rzeczą w świecie, lecz pewną szczególną perspektywą narzuconą światu. Mówiąc inaczej, narody są efektem pewnego kulturowo uwarunkowanego sposobu konstruowania rzeczywistości społecznej - są zatem tworami intencjonalnymi" [Burszta, Jaskułowski 2005: 13]. Ujęcie to wskazuje na funkcjonowanie narodu jako „wspólnoty wyobrażonej”, posługując się najbardziej nośną koncepcją narodu ostatnich lat. Benedict Anderson [1997] wskazywat, że naród jest tworem o charakterze symbolicznym, co nie znaczy, że nie istnieje obiektywnie. Świetnie wytłumaczył to Krzysztof Jaskułowski [2009: 211] pisząc, że „(...) wedle Andersona naród jest wytworem (artefaktem) przynależącym do sfery kultury, który powstał pierwotnie w sposób niezaplanowany w określonym miejscu i czasie; nie może więc być traktowany jako zjawisko naturalne czy odwieczne, ale nie można go również ujmować w kategoriach ideologicznej manipulacji (choć później mógł być w takim celu wykorzystany)". Naród jest więc Tönniesowskim stowarzyszeniem (Gesselschaft) wyobrażonym i odczuwanym przez ludzi jako wspólnota (Gemeinschaft).

Z perspektywy antropologicznej nie jest ważne, jaki status prawny ma dana grupa, ale jak jej działania i dążenia wpływają na wyobrażenia i świadomość jej członków. Jeśli naród traktować jako byt, który tworzy się w określonym miejscu i czasie, a istnieje dlatego, że wchodzące w skład wspólnoty jednostki odczuwają łączące je związki, jeśli tworzą (i odtwarzają) wspólną historię, uczą się mitów założycielskich i posiadają własne instytucje spajające tę niepołączoną wcześniej tak silnie grupę ludzi, wówczas określanie definitywne i jednoznaczne jakiejś grupy jako narodu lub nie-narodu jest nieprawomocne. Co nie 
znaczy, że dyskusje nad tym zagadnieniem nie powinny mieć miejsca, bądź że nie mają znaczenia dla danej wspólnoty. To one bowiem ją kształtują i wpływają na świadomość poszczególnych jednostek. Zaś istnienie tej świadomości może zmienić status grupy zarówno w jej własnych oczach, jak i w odczuciu otaczających ją wspólnot - wszakże narody są tworami intencjonalnymi.

Niezależnie od tego, zajmowanie się problematyką związaną z kaszubskim dyskursem narodowościowym jest trudne, gdyż dyskusja wokół kaszubskiego narodu jest głęboko osadzona w kontekście politycznym. Wydaje się, że istotnym problemem w myśleniu dziś o narodzie jest trwałość dziewiętnastowiecznej koncepcji państwa narodowego. Wedle tej koncepcji mniejszość autochtoniczna nie powinna pretendować do miana narodu, bo oznaczałoby to jej dążenie do uzyskania autonomii, a nawet pewnej formy niepodległości. Ewa Nowicka [2009: 10] w tekście Kulturowa odmienność w działaniu. Narody duże i małe, stare i mtode w ten sposób opisuje nośność tej koncepcji:

„(...) nazywanie grupy narodem niesie ze sobą określone konsekwencje dla grupy, której ma być przypisana taka kwalifikacja. Najważniejsze z tych konsekwencji wydają się następujące: 1) rodzaj prestiżu wynikającego w powszechnym odczuciu z przynależności do narodu; 2) możliwość ubiegania się o różne przywileje, zarówno w granicach politycznych jednego państwa, jak i na arenie międzynarodowej".

Takie definiowanie narodu powoduje z jednej strony, że grupa dążąca do posiadania takiego statusu uważana jest przez dominującą większość za zagrożenie. Z drugiej strony, Kaszubi dążący do przyznania im statusu narodu na te właśnie przywileje płynące z samej nazwy się powołują w swoich postulatach. Przedstawiciele Stowarzyszenia Osób Narodowości Kaszubskiej „Kaszëbskô Jednota” twierdzą, że jeśli Kaszubi nie zostaną uznani za naród, nie będą mieli dostępu do środków, jakie są potrzebne, by rozwijać tożsamość kulturową, którą niewątpliwie posiadają. Dlatego trzeba ich uznać za naród, żeby kiedyś mogli taką wspólnotę (świadomie) stworzyć. Wbrew pozorom twierdzenie to nie zawiera błędu logicznego. Pojęcie "naród” zostało tu użyte w trzech różnych znaczeniach: jako termin prawny (dać Kaszubom status narodu: mniejszości narodowej lub etnicznej), jako wspólnota kulturowa (Kaszubi mają swoją kulturę i zbiorową tożsamość) i wreszcie jako wspólnota polityczna (którą będą mogli stworzyć jedynie rozwijając zbiorową świadomość przynależności do odrębnej od polskiej grupy). Dlatego też między Zrzeszeniem Kaszubsko-Pomorskim, które głosi ideologię Kaszubów-patriotów, Kaszubów o podwójnej tożsamości, a działaczami "Kaszëbskô Jednoty” nawołującymi do wyboru "narodowości kaszubskiej” w celu rozwijania wspólnoty w kategoriach politycznych, nie może na razie być zgody. JAKO KONTEKST KASZUBSKIEGO DYSKURSU NARODOWOŚCIOWEGO

W ostatnich latach na Kaszubach prowadzone są liczne, na niespotykaną wcześniej skalę, kampanie na rzecz Kaszub, kultury kaszubskiej i kaszubskiego języka. Równolegle do nich pojawiają się dyskusje prowadzone na różnych szczeblach i przez różne organizacje i jednostki. Część tych działań wynika z prowadzonej w XXI wieku w Polsce polityki mniejszościowej. W 2005 roku została przyjęta przez Sejm „Ustawa o mniejszościach narodowych i etnicznych oraz języku regionalnym". Prace nad tą ustawą trwały kilkanaście 
lat nie tylko z powodu licznych zmian politycznych i opinii, ale także dlatego, że sprawa mniejszości w jednonarodowej i jednokulturowej powojennej i pokomunistycznej Polsce jest kwestią delikatną i to zarówno dla politycznych decydentów, jak i dla mniejszości. Już samo określenie statusu, jaki w Polsce powinni posiadać Kaszubi, było wyzwaniem. Kaszubi w latach 90. XX wieku zyskali szereg przywilejów jako "grupa etniczna" [Łodziński 2007: 158]. Już wtedy niektórzy działacze kaszubscy podkreślali, że Kaszubi nie są mniejszością, a właśnie regionalną grupą etniczną, pielęgnującą odrębność kulturową i językową, a jednocześnie mającą „naturaln e poczucie przynależności do szerszej wspólnoty narodowo-państwowej” (wszystkie podkreślenia w tekście NDR) [Synak 1991: 85]. Wielu Kaszubom już sam termin „mniejszość” kojarzył się pejoratywnie, gdyż takie określenie mogło ich zdaniem pociągnąć za sobą negatywne konsekwencje dla społeczności kaszubskiej w postaci dyskryminacji. Inni argumentowali, że nie chcą być nazywani mniejszością, skoro na swoim terenie stanowią większość, deklarując na dodatek podwójną, polsko-kaszubską tożsamość [Łodziński 2007: 145-169]. Samo pojawienie się takich obaw ze strony Kaszubów świadczy bardziej o głęboko zakodowanym w kaszubskiej zbiorowej pamięci strachu przed wykluczeniem i byciem uznanym za "innego" czy "obcego" niż o skutecznej asymilacji kulturowej. Kaszubi bowiem byli bardzo aktywni w pracach nad Ustawą, chcieli by ich język i kultura została objęta ochroną. Woleli jednak nie musieć deklarować przynależności etnicznej, żeby nie prowadzić do sąsiedzkiego konfliktu [por. Jawor 2009, Pasieka (w druku)]. Dlatego też, za radą językoznawców Alfreda Majewicza i Tomasza Wicherkiewicza, postanowiono skoncentrować się nie na trudnym dla samych Kaszubów statusie grupy, lecz na ich języku, który został uznany w Ustawie za język regionalny Polski. Tym samym Kaszubi zyskali status grupy posługującej się językiem regionalnym. Dzięki ochronie zagwarantowanej przez państwo (która ogranicza się co prawda do dotacji finansowych), kaszubski wszedł do szkół² ${ }^{2}$ do kościoła ${ }^{3}$, funkcjonuje w mediach (choć na bardzo ograniczoną skalę), obecny jest również w wizualnym otoczeniu ludzi: na dwujęzycznych tablicach, znakach, nazwach obiektów (zwłaszcza turystycznych). Kaszuby stały się regionem atrakcyjnym turystycznie już nie tylko ze względu na piękno krajobrazu (morze, jeziora, góry, lasy), ale również jako region posiadający swoją specyfikę kulturową. To zainteresowanie zaczęli wykorzystywać sami Kaszubi propagując coraz silniej kaszubskość jako atrakcję turystyczną. Od kilku lat na Kaszubach organizowanych jest coraz więcej festiwali i pikników kaszubskich, spotkań regionalnych, dni poszczególnych miast i miejscowości, w czasie których pojawiają się kaszubskie symbole, stroje, muzyka i jedzenie. W ten sposób kaszubskość staje się nie tylko coraz bardziej widoczna, wpisując się w kulturowy krajobraz Pomorza, ale też modna.

Z jednej strony nowy wymiar kaszubskości włączył się w codzienne życie ludzi, z drugiej pojawiły się inicjatywy i działania kaszubskich elit, nastawione na umocnienie „wyobrażonych" więzi kaszubskich, na stworzenie z Kaszubów ponadlokalnej wspólnoty. Od 15 lat organizowane są co roku Zjazdy Kaszubów (upamiętniające reformę admini-

\section{......}

Alfred Majewicz i Tomasz Wicherkiewicz dowodzą, że kaszubski zalicza się do języków regionalnych, czyli używanych przez poszczególne autochtoniczne grupy etniczne, często blisko spokrewnionych z językami większości (przez co dyskusyjny bywa ich status lingwistyczny), nie posiadających statusu języka oficjalnego, używanych na ogół w wielu odmianach dialektalnych [Majewicz, Wicherkiewicz 2001: 87-88].

2 Obecnie kaszubskiego uczy się koło 15000 uczniów na różnych poziomach edukacji (głównie w szkołach podstawowych, 82\% i gimnazjach, 15\%) [https://mail.google.com/mail/u/0/?shva=1\#inbox/13f8a5900a244 1 b8 (wejście 4.07.2013)]. Jednak jest to tzw. „edukacja słaba”, która zdaniem ekspertów nie prowadzi do dwujęzyczności, a jedynie do zapoznania się w językiem traktowanym jako "obcy" [Skutnabb-Kangas 2000: 579-580]: kaszubski nauczany jest 3 godziny tygodniowo na dodatkowych (nieobowiązkowych) lekcjach.

3 Początkowo również z oporami nie tylko ze strony księży, ale też Kaszubów [patrz Dołowy-Rybińska 2011: 477-482]. 
stracyjną z 1999 roku i znalezienie się Kaszubów w jednym województwie pomorskim). Od 2004 roku obchodzony jest Dzień Jedności Kaszubów, święto upamiętniające pierwszą pisemną wzmiankę o Kaszubach z 18 marca 1238 roku w bulli papieża Grzegorza IX. W 2012 roku miały miejsce po raz pierwszy obchody Święta Flagi Kaszubskiej. Tego typu działania można nazwać „tradycjami wynalezionymi”, które przez swoją symbolikę i powtarzalność ustanawiają ciągłość i służą „wzmacnianiu poczucia przynależności oraz symbolizowaniu jedności wewnętrznej grup i rzeczywistych lub sztucznych wspólnot" [Hobsbawm 2008:18]. Takie organizowane co roku uroczystości działają na wyobraźnię ludzi, umacniają ich w poczuciu, że ich kultura istnieje, jest ciekawa i ważna, a przede wszystkim: stwarzają poczucie związku z innymi, nieznanymi bezpośrednio, Kaszubami [por. Anderson 1997: 19].

Kolejnym czynnikiem istotnym dla umacniania się kaszubskiej wspólnoty wyobrażonej były dwa Spisy Powszechne, które miały miejsce w 2002 i 2011 roku. Pierwszy z nich zakończony był wielką i burzliwą dyskusją, zaś mniejszości wytykały organizatorom źle przygotowany, bo nieuwzględniający praktycznie kwestii etnicznych, formularz, wadliwie skonstruowane pytania, wreszcie niekompetencję przeprowadzających Spis urzędników, a w wielu przypadkach (w tym na Kaszubach) - również ich złą wolę [Adamczuk, Łodziński 2006]. Wkrótce po ogłoszeniu wyników Spisu Powszechnego z 2002 roku po raz pierwszy pojawiła się publicznie kaszubska kwestia narodowa, gdyż 5100 osób zadeklarowało wówczas kaszubską narodowość, co od razu wywołało w środowisku kaszubskim poruszenie. Drugi Spis został na Kaszubach poprzedzony istotnymi przygotowaniami i kampaniami prowadzonymi przez Zrzeszenie Kaszubsko-Pomorskie. Zorganizowana została kampania „Jo!Tak! Jëm Kaszebą!” [http://www.spis.kaszubi.pl/], w ramach której organizowane były liczne spotkania z lokalnymi kaszubskimi wspólnotami, w czasie których namawiano Kaszubów do wzięcia udziału w Spisie i zadeklarowania kaszubskiej tożsamości oraz używania kaszubskiego języka. O Spisie wiele mówiło się w kaszubskich mediach, na spotkaniach, uroczystościach. Wydaje się, że po raz pierwszy na tak dużą skalę Kaszubi zaangażowali się we wspólne działanie, które z kolei miało niewątpliwy wpływ na wzmocnienie wyobrażonej kaszubskiej wspólnoty i ponadlokalnej kaszubskiej tożsamości. W Spisie 2011 roku 233 tysiące osób zadeklarowało jakąś formę kaszubskiej tożsamości. W grupie tej znalazło się 18 tysięcy osób deklarujących kaszubską narodowość ${ }^{4}$. Wyników obu Spisów nie można porównywać, gdyż nie mają wspólnej metodologii ani identycznych pytań. Niewątpliwie jednak warte odnotowania jest zainteresowanie wśród Kaszubów drugim Spisem i bardziej otwarta niż przed dziesięciu laty deklaracja kaszubskiej tożsamości, na którą wpływ miały prowadzone wokół kaszubskiej wspólnoty działania.

Inicjatywy przodowników kultury, mówiąc za Florianem Znanieckim, mają istotne znaczenie dla tworzenia narodów [Znaniecki 1990: 368]. Do kaszubskich przodowników zaliczyć trzeba kaszubską inteligencję i działaczy, którzy w aktywny sposób wpływają na zwykłych ludzi, zachęcając ich do podejmowania indywidualnych działań. Obecnie kaszubska elita skupiona jest w dwóch organizacjach: Zrzeszeniu Kaszubsko-Pomorskim [zwanym dalej w tekście ZK-P] i Stowarzyszeniu Osób Narodowości Kaszubskiej „Kaszëbskô Jednota" [oznaczanym dalej skrótem KJ]. ZK-P jest jednym z największych stowarzyszeń w Polsce, działającym na prawach Organizacji Pożytku Publicznego, zrzeszającym koło 5000 członków w kilkudziesięciu oddziałach terenowych. Istnieje od 1956 roku, w III RP stało się organizacją odpowiedzialną za kształtowanie polityki kulturalnej i językowej Ka-

4 Wyniki te - jak deklaruje GUS - mogą wciąż ulec nieznacznej zmianie. http://www.stat.gov.pl/cps/rde/xbcr/ gus/Przynaleznosc_narodowo-etniczna_w_2011_NSP.pdf (28.06.2013). 
szubów ${ }^{5}$. Do niedawna było jedyną w ogóle kaszubską organizacją. Tymczasem stowarzyszenie KJ założone zostało w 2011 roku jako wyraz buntu przeciw prowadzonej przez ZK-P kampanii wykluczającej możliwość podawania w Spisie Powszechnym kaszubskiej narodowości. Stowarzyszenie ma kilkudziesięciu członków, wykorzystujących jednak bardzo sprawnie technologie XXI wieku. Zdaję sobie sprawę, że dla wielu osób samo zestawienie ze sobą tych dwóch nierównych sił jako współkształtujących kaszubską wspólnotę wyobrażoną może być kontrowersyjne. Nie na kontrowersji mi jednak zależy, ale na ukazaniu, w jaki sposób pojawienie się na scenie kaszubskiej drugiej organizacji wpłynęło na rozwój kaszubskiego dyskursu narodowościowego i jak jest on kształtowany. Z perspektywy antropologicznej interesująca jest obserwacja, jak dyskusje i działania inicjowane przez kaszubskie elity wpływają na ludzi, ich postawy, sposób myślenia, dyskurs. Podkreślić trzeba też, że jest to obserwacja zjawiska, które w tej chwili się rozgrywa, co więcej, jest ono skomplikowane i niejednoznaczne, choćby dlatego, że nie jesteśmy w stanie przewidzieć, na ile sam kaszubski dyskurs narodowy wpłynie na zwykłych Kaszubów, ich deklaracje i świadomość.

\section{KONTEKST KASZUBSKIEGO DYSKURSU NARODOWOŚCIOWEGO}

Dyskusja o kaszubskiej narodowości idzie w parze, a może nawet jest pokłosiem dyskusji dotyczącej narodowości śląskiej. Ta ostatnia ma już w Polsce długą tradycję. To Ślązacy w pierwszym Spisie Powszechnym z 2002 roku zaskoczyli wszystkich decydując się bardzo licznie (ponad 173 tys. osób) na podanie narodowości śląskiej. To oni domagali się długo i we wszystkich możliwych instancjach legalizacji Stowarzyszenia Osób Narodowości Śląskiej (nieprzypadkowo „Kaszëbskô Jednota” jest Stowarzyszeniem Osób Narodowości Kaszubskiej). Wreszcie wokół tej dyskusji powstało wiele książek (zarówno naukowych, jak i publicystycznych) [por. Nijakowski 2002, Nijakowski 2004; Sekuła 2009], a przede wszystkim głośnych, bo wspartych medialnie, oskarżeń politycznych (w tym o "zakamuflowanej opcji niemieckiej"6). Analiza śląskiego dyskursu narodowego wymagałaby więc użycia innych, niż w przypadku kaszubskiego, źródeł. Najcenniejszych danych dostarczyłyby media, które z obawą przyglądają się działaniom Ślązaków, ich dążeniom do autonomii (często nazywanej przez dziennikarzy i polityków „separacją”), a także walki o uznanie istnienia śląskiego języka i jego ochrony prawnej. Kaszubskie działania rozpoczęły się w innym miejscu: od nadania kaszubskiemu statusu języka regionalnego i promocji Kaszub jako regionu o silnej kulturze. Do tej pory jednak Kaszubi nigdy nie wysuwali haseł, które (niesłusznie zresztą) większość polska mogłaby uznać za niebezpieczne. A takimi hasłami, jak starałam się wyżej pokazać, mogą wydawać się postulaty uznania Kaszubów za naród. Działacze stowarzyszenia KJ nawiązują do Ślązaków nie tylko w nazwie. Od samego początku utrzymują ścisłe kontakty ze śląskimi aktywistami, przyznają się do inspiracji tym ruchem, nawiązują do niego i proponują połączone działania na rzecz obu społeczności, czego przykładem jest wspólne złożenie propozycji nowelizacji ustawy o mniejszościach [http://sejmometr.pl/legislacja_projekty_ustaw/301]. Istnienie obok Ślązaków, których świadomość narodowa jest silna (w ostatnim Spisie 847000 osób wybra-......

5 ZK-P deleguje przedstawicieli w Komisji Wspólnej Rządu i Mniejszości Narodowych i Etnicznych, ale też
stworzyło Radę Języka Kaszubskiego, która jest odpowiedzialna za kształtowanie polityki językowej na Ka-
szubach.
Podobne oskarżenia padały również pod adresem Kaszubów, czego przykładem jest „dziadek z Wehrmachtu”. 
to narodowość śląską), daje Kaszubom chcącym uznania swojej grupy za naród, rozgłos medialny. Równocześnie stawia ich jednak (w oczach części społeczeństwa) w pozycji osób potencjalnie niebezpiecznych dla polskiej suwerenności.

To właśnie przeraża Kaszubów, którzy boją się kłopotów i niechęci ze strony Polaków. Na ten aspekt zwraca też uwage prof. Brunon Synak, socjolog, jeden z czołowych Kaszubów-naukowców, a także działacz ZK-P. W wywiadzie, który ukazał się pod artykutem o stowarzyszeniu KJ [„Norda. Tygodnik Kartuzy” z 2.03.2013], powiedział: „Kiedyś władze miasta postawiły tu taka sympatyczną tablicę z napisem Gdańsk stolica Kaszub wita $^{7}$. Kilka dni temu została ona zamalowana na niebieski kolor. To niestety może być właśnie pokłosie debaty o Kaszubach jako mniejszości". Nie wiadomo, czy zniszczenie tablicy miało jakikolwiek związek z dyskusją o kaszubskiej narodowości, czy było to dziatanie wymierzone specjalnie w Kaszubów, czy też zwykły akt wandalizmu. Jednak już samo zestawienie tych faktów wywołuje efekt zastraszania: jeśli będziemy jako Kaszubi się wychylać, starać się coś zmienić, jeśli nie będziemy chcieli być Polakami (bo taki wykluczający argument bardzo często pada w wypowiedziach), wówczas będziemy narażeni na ataki i niechęć innych osób. Pamiętajmy, że Kaszubi w swojej historii - ze względu na zamieszkiwanie w newralgicznej strefie konfliktów polsko-niemieckich - bardzo często musieli udowadniać, że są dobrymi obywatelami i Polakami. W tym samym wywiadzie Synak podkreśla dodatkowo, że przyjęcie określenia „mniejszość" spowoduje wykluczenie Polaków zamieszkałych na Kaszubach z działań na rzecz regionu i może się odbić ich niechęcią w stosunku do samych Kaszubów.

\section{ANALIZA KASZUBSKIEGO DYSKURSU NARODOWOŚCIOWEGO}

Dziś już samo pojęcie dyskursu jest problematyczne. Zwrócił na to uwage David Howarth wskazując na wielość sposobów rozumienia pojęcia dyskursu przez badaczy związanych z różnymi dziedzinami nauki [Howarth 2008: 14-18]. W węższym rozumieniu dyskurs odnosi się do użyć języka, wystąpień, aktów mowy i pisma. W szerszym, interesującym mnie zakresie, dyskurs odnosi się nie tylko do sposobów mówienia, ale i do propagowanych przez mówiących idei i koncepcji [Kawka 2011: 91-92]. Dyskurs traktować będę więc jako język, którego badanie wymaga analizy zarówno języka jak i jego działanie [Blommaert 2005: 2]. Analiza dyskursu, na który składają się różne gatunki, opierać się będzie na kilku typach źródet:

1) pracach naukowych przedstawiających poglądy na temat kaszubskiej narodowości tworzonych przez naukowców-Kaszubów, związanych ze środowiskiem ZK-P;

2) dokumentach propagandowych KJ, zwłaszcza publikacji Artura Jabłońskiego „Kaszubi. Wspólnota narodowa" [2013];

3) materiałach medialnych (gazety, programy telewizyjne, a zwłaszcza fora internetowe i strona KJ;

4) wywiadach z młodymi Kaszubami należącymi do dwóch organizacji: Klubu Studenckiego „Pomorania" (działającego przy ZK-P, dalej oznaczonym jako KS „Pomorania”) oraz stowarzyszenia KJ.

7 Charakterystyczne jest to, że w gazecie treść napisu została podana po polsku, choć spór dotyczył nie tylko niezgody części społeczności na nazywanie Gdańska stolicą Kaszub, ale również tego, że język kaszubski wchodzi w wizualną przestrzeń Gdańska. Napis na tablicy brzmi w oryginale: „Gduńsk stolëca Kaszëb witô". 
W analizie tej język i sposoby użycia języka służyć będą wyjaśnieniu szerszego spektrum zjawisk społecznych.

Analiza dyskursu tworzonego przez kaszubskich działaczy, aktywistów i kaszubskie elity intelektualne stanowi ważne źródło do zrozumienia współczesnej kultury kaszubskiej, przemian, które się w niej w tej chwili dokonują, a także dylematów Kaszubów oraz wyzwań, jakie przed nimi stoją. Następnym etapem badań powinna być analiza sposobu mówienia zwykłych Kaszubów o kwestii narodowościowej i wpływie na nią dyskursu oficjalnego. W tym tekście analizie podaję przede wszystkim dyskurs publiczny: tworzony przez naukowców, polityków, działaczy. Dyskurs, który oni sami tworzą dla siebie, jak i dla społeczności, którą reprezentują, a więc na którą chcą wpływać i którą chcą kształtować. Trzecia część analizy dotyczy przekazu medialnego na temat kaszubskiej kwestii narodowej. Jak się okaże, media nie mają dużego wpływu na kształtowanie tego dyskursu, a jedynie go prezentują. Tym samym są również wykorzystywane do upowszechniania obowiązującego sposobu mówienia o statusie Kaszubów. Dopiero w ostatniej części analizuje głos tych, którzy nie wypowiadali się w celu kształtowania niczyjej postawy ani świadomości. Są to słowa młodych osób (do 25. roku życia), które kierowali do mnie wiedząc, że będą to głosy prezentowane anonimowo. Dopiero ja, wybierając wypowiedzi i analizując je, również na tle prowadzonych przeze mnie od wielu lat badań i obserwacji uczestniczącej oraz znając publiczny kaszubski dyskurs narodowościowy, umieszczam je w tym konkretnym kontekście, pokazując jednocześnie, jaki oddźwięk ten publiczny dyskurs ma na sposób mówienia młodych ludzi oraz na ich postrzeganie rzeczywistości spotecznej, której sami również są aktorami.

\section{1. Źródta naukowe}

Jeśli prace naukowe potraktować jako źródło, a nie jako odniesienie, trzeba zwrócić uwagę na te cechy naukowego dyskursu, które w czytaniu prac jako naukowych, wydają się nieistotne. Tymczasem w odczycie antropologicznym zyskują nową wartość poznawczą. Potraktować je trzeba jako „tubylcze”, mówiąc za Kirsten Hastrup, pisma, które nie mogą zastąpić badań etnograficznych, stanowią natomiast dla tych badań dodatkową inspirację i przedmiot analizy [Hastrup 2008: 45]. Badania naukowe (zwłaszcza socjologiczne) dotyczące Kaszubów, prowadzone już po 1989 roku, wpisane były w szczególny kontekst. Z jednej strony zmieniające się warunki polityczne dały Kaszubom szansę na wyjście z impasu i walkę o zapewnienie swojej kulturze i językowi należnej ochrony ze strony państwa, z drugiej jednak, zmiany te wymagały precyzyjnego (bo mającego mieć swoje odzwierciedlenie w prawnych dokumentach) określenia statusu Kaszubów. A ten zawsze był sprawą problematyczną [por. Obracht-Prondzyński 2006, Dołowy 2008]. Problematyczny był m.in. dlatego, że „w praktyce większość badaczy spraw kaszubskich to sami Kaszubi. (...) Zarazem są też działaczami i ideologami ruchu kaszubskiego, stanowiąc elitę kulturalną. Aktywnie kształtującą samą kaszubskość według świadomie założonego projektu" [Nowicka 2007: 85]. Kaszubscy naukowcy podejmowali więc badania będąc wewnątrz badanej społeczności, starając się jednocześnie zachować jak największy obiektywizm. Niezależnie od najlepszych nawet intencji, naukowiec zawsze wpływa na wyniki badań, formułując takie a nie inne wnioski, zadając w taki a nie inny sposób pytania, wybierając taką a nie inną grupę badanych, wreszcie: wybierając i odpowiednio zestawiając i komentując wypowiedzi. Nie jest to jednak manipulacja, a postępowanie zgodnie z metodologią opartą na „współczynniku humanistycznym” [Znaniecki 1973: 
28-36]. Naukowiec będący częścią badanej społeczności posiada o niej z góry nadane założenia, uznając je łatwiej za bezwzględnie obowiązujące, gdyż w nich wyróst i są one częścią jego kultury, od której trudno mu się zdystansować. Naukowiec, który sam czuje się za przyszłość badanej przez siebie wspólnoty odpowiedzialny, znajduje się w jeszcze trudniejszej sytuacji. Nie chcę przez to powiedzieć, że w związku z tym, wyniki takich badań są nieważne. Chcę jedynie podkreślić, że - jak wszystkie badania humanistyczne - osadzone są w pewnym konkretnym kontekście, w którym znajduje się zarówno grupa badana, jak i sam badacz.

Przykładów naukowego dyskursu dotyczącego statusu Kaszubów (a więc również kwestii narodowej) można podać wiele, kilka znalazło się już w tym artykule. Znajdują się zarówno w socjologicznych pracach naukowych, wykluczających pojawienie się innych od ustanowionej koncepcji (np.: „Wydaje się, że dominujące jest obecnie stanowisko, że kaszubszczyzna to 'osobny język słowiański', c o oczywiście wcale nie oznacza, że Kaszubi posiadają odrębną świadomość narodową, bowiem w wielu badaniach socjologicznych wyraźnie udokumentowano, że specyfiką Kaszubów jest posiadanie przez nich podwójnej tożsamości: etnicznej-kaszubskiej i narodowej-polskiej" [Obracht-Prondzyński 2002: 332]), jak i można usłyszeć je podczas rozmów z Kaszubami-naukowcami ${ }^{8}$. Ten sposób podkreślania istnienia jednego obowiązującego sposobu opisu i kategoryzacji Kaszubów jest nie tylko wnioskiem płynącym z badań. Jest również (jak w powyższym cytacie) zabezpieczeniem się przed możliwością, by z tych badań zostały wysunięte inne wnioski. Sami naukowcy wydają się uważać, że kategorii tych nie należy - dla dobra wspólnoty i, jak twierdzą, dla rzetelności naukowej - podważać lub kwestionować. Cytowany już prof. Cezary Obracht-Prondzyński w innym tekście dał wyraz temu przekonaniu pisząc, że „za funkcjonowanie siatki pojęciowej, przy pomocy której dyskutuje się o tym, kim są Kaszubi, odpowiadają w różnym stopniu środowiska naukowe oraz elita (inteligencja) kaszubska, co zresztą w pewnej mierze się ze sobą pokrywa. To one ostatecznie wypracowały w latach osiemdziesiątych i dziewięćdziesiątych ubiegłego wieku model terminowy, opisujący tę społeczność" [Obracht-Prondzyński 2009: 70-71]. Z takim stwierdzeniem trudno polemizować. Model terminowy opisujący Kaszubów został "ostatecznie wypracowany". Co więcej, jest to model, który - w zamyśle jego twórców - gwarantuje Kaszubom najlepsze możliwości i odzwierciedla sposób, w jaki oni (naukowcy, a więc i Kaszubi) odczuwają swoją tożsamość. To między innymi jest jednym z głównych powodów zdenerwowania, jakie towarzyszyło od początku pojawieniu się kaszubskiej opcji narodowej. To ona bowiem zaburza istniejący status quo opisu kaszubskiej wspólnoty. Wydaje mi się, że właśnie z obawy o utratę monopolu kaszubscy naukowcy niechętnie patrzyli na zajmujących się Kaszubami badaczy "z zewnątrz", którzy - jak sama to często słyszałam - nie są w stanie zrozumieć kaszubskiej specyfiki i mogą zostać zwiedzeni atrakcyjnymi hasłami narodowców. Wraz z założeniem stowarzyszenia KJ kwestia narodowa przebiła się silniej do mediów, do dyskursu publicznego, a przez to naukowcy i ich dyskurs zszedł na dalszy plan, pierwszy zostawiając działaczom etnicznym, przodownikom kaszubskiej kultury (nawet jeśli Kaszubi-naukowcy również się w tej grupie znajdują).

8 Więcej na ten temat pisałam przed kilku laty w tekście Kaszubi - naród, mniejszość, grupa postugująca się jezzkiem regionalnym (Dołowy 2008: 74-79). 


\section{2. Źródła informacyjno-propagandowe}

Każda ideologia, zwłaszcza ideologia nowo kształtująca się, potrzebuje propagandy, jasnych i trafiających do opinii publicznej haset i zwrotów, dzięki którym przyciągnięci zostaną do niej nowi zwolennicy. Działania ZK-P w sferze związanej z interesującą nas dyskusją polegają w tej chwili głównie na zaprzeczaniu istnienia "kaszubskiej narodowości", wytykaniu działaczom KJ zachłanności, promowania własnych interesów, tworzenia bytów, które nie istnieją. Po założeniu KJ, ZK-P cofnęło Arturowi Jabłońskiemu, czołowej postaci nurtu narodowego, rekomendację na przedstawiciela ZK-P w Komisji Wspólnej Rządu i Mniejszości Narodowych i Etnicznych. Mimo nieprowadzenia dyskusji na temat kaszubskiej narodowości i odcinania się od niej, temat ten się pojawia na prawie wszystkich spotkaniach członków lub sympatyków ZK-P, zarówno tych oficjalnych, jak i tych lokalnych, a także nieformalnych, pod postacią niechęci pod adresem KJ i jej działaczy oraz wyliczania strat, jakie środowisko kaszubskie oraz sami Kaszubi w związku z tym poniosą.

Tymczasem większość działaczy KJ to osoby młode, które chętnie publicznie zabierają głos, mają prężnie działającą stronę internetową, pokazują się w mediach, wypowiadają i udzielają wywiadów. Nie ukrywają, że inspiracją dla ich działań były wydarzenia i dyskurs narodowościowy rozgrywający się na Śląsku. Choć środowisko tworzące KJ jest bardzo małe, liczba ich sympatyków, a w każdym razie osób, na które środowisko to oddziałuje, rośnie.

Działacze KJ korzystają z każdej okazji, żeby udowodnić tezę o odrębności Kaszubów i Polaków. Odrębność ta wydaje się warunkiem koniecznym, żeby istnienie kaszubskiego narodu mogło zostać publicznie zaakceptowane. KJ publikuje więc na swojej stronie internetowej kolejne, opracowane fragmenty publicystyki Zrzeszeńców, uważanych za prekursorów kaszubskiego ruchu narodowego i prześladowanych po II wojnie światowej za swoje poglądy, które dziś można nazwać autonomistycznymi. Organizuje wiele imprez, podkreślając wage używania języka kaszubskiego i propagowania kaszubskiej myśli na zewnątrz. Na stronie facebookowej komentowane są również wydarzenia, publikacje czy opinie, które dotyczą Kaszubów. Jako przykład wybrałam komentarz do dyskusji, jaka powstała na portalu YouTube w związku z zamieszczeniem tam nagrania z wejherowskiego zwyczaju pokłonów feretronów ${ }^{9}$. Zwyczaj ten jest tłem dla interesującego mnie komentarza zamieszczonego na Facebooku KJ: „Kaszubska tradycja hitem internetu. Wyśmiewanie i drwiny zamiast zrozumienia i poszanowania - oto przykład tego, ja k bar dzo kaszubska kultura może różnić się od polskiej oraz jakienieporozumienia mogą za sobą nieść różnice w dziedzictwie kulturowym dwóch odrębnych nacji żyjących w jednym kraju" [https://www.facebook.com/Kaszebi?fref=ts]. Tradycja religijna i reakcja na nią społeczeństwa polskiego stały się okazją do podkreślenia odmienności wynikającej z przynależności do dwóch narodów.

Najciekawszym źródłem dotyczącym dyskursu narodowościowego na Kaszubach jest książeczka Kaszubi. Wspólnota narodowa. Artur Jabłoński, jej autor, związany początkowo z "Tatczëzną", następnie prezes ZK-P - mimo głoszenia już wtedy podglądów narodowościowych, reprezentujący długo Kaszubów w Sejmowej Komisji ds. Mniejszości, jest jednym z inicjatorów założenia „Radia Kaszëbë” i założycielem istniejącej niedługo

9 W ciągu kilku dni liczba udostępnień pod filmikiem z Wejherowa wyniosła kilkaset tysięcy, zaś komentarze często miały charakter ksenofobiczny. O „sukcesie” filmiku świadczyć może fakt, że Kaszubi, o których w publicznych mediach rzadko się mówi, znaleźli się we wszystkich programach informacyjnych jako ci, co "tańczą z feretronami". 
telewizji kaszubskiej CSBTV oraz szarą eminencją stowarzyszenia KJ. Książeczka, którą Jabłoński napisał w 2012 i wydał w 2013 roku, jest manifestem poglądów autora oraz interpretacją wydarzeń rozgrywających się na Kaszubach od upadku komunizmu do dziś. Poetyka tej publikacji utrzymana jest w oskarżycielskim wobec ZK-P, związanych z nim naukowców i działaczy, tonie. W każdym niemal zdaniu Jabłoński dowodzi, że działania ZK-P prowadzone były celowo przeciw kaszubskiej opcji narodowej, którą decydenci uważali z różnych powodów za szkodliwą („Taka definicja dawała bezpieczeństwo i - co należy podkreślić - akceptację działań wewnętrznych w samym ZK-P, jednocześnie oddalając zewnętrzne oskarżenia o separatyzm" [Jabłoński 2013: 12]; ZK-P opowiada „jedną tylko - słuszną - opowieść" [lbid.: 14]; „niebezpieczeństwo choćby przymiarki do narodowego odrodzenia Kaszubów zostało zręcznie zażegnane" [lbid.: 15]). Mamy więc w publikacji bohatera negatywnego. Pozytywnym jest oczywiście środowisko osób, z którym autor od początku był związany, ludzi, którzy wiedzieli, że dla Kaszubów i ich przyszłości tylko uznanie statusu narodu jest szansą. To działaniom tych ludzi przypisany jest sukces zmiany statusu języka kaszubskiego. Co więcej, Jabłoński pisząc o Kaszubach używa pierwszej osoby liczby mnogiej „my”, dzięki czemu nie ma wątpliwości, że wszyscy, którzy Kaszubami się naprawdę czują, identyfikują się z głoszonymi przez autora tezami, a także, że Jabłoński reprezentuje Kaszubów jako wspólnotę („Największym s u k c e s e m n u rtu e tnic zn e go w latach dziewięćdziesiątych XX wieku była zmiana nastawienia Kaszubów do własnego języka. Kaszubszczyzna dla większości przestała być mową wsi. Stała się jednym z fundamentów tożsamości Kaszubów - n a s z e j autoidentyfikacji") [lbid.: 20].

W drugim rozdziale Jabłoński tłumaczy motywację własnego zaangażowania: „Od co najmniej dziesięciu lat jestem przekonany, że najlepszą formułą ochrony kaszubskiego potencjału kulturowego jest ochrona, ugruntowanie i rozwój tożsamości narodowej Kaszubów" [lbid.: 27]. Ta nie rozwinęła się, gdyż była „z m ą c o n a tym wszystkim, co przypisywali nam ludzie pochodzący spoza naszego kręgu kulturowego" [lbid.: 27]. Mącona natomiast była przez tych, dla których wygodnie było, żeby Kaszubi uważali się za Polaków i nie myśleli o sobie w kategoriach narodowych. W tekście Jabłońskiego można więc usłyszeć echa teorii i dyskursu post-kolonialnego [por. Barker, Hulme, Iverson 1996]. Konsekwencją działań ZK-P jest według Jabłońskiego to, że „dziś chronimy i rozwijamy język, który przestał pełnić swoją podstawową funkcję - narzędzia komunikacji. Kaszubskie dzieci uczą się go w szkołach, w większości nie wiedząc po co i traktując mowę ojczystą jak jeszcze jeden dodatkowy przedmiot. Kładąc akcent wyłącznie na ochronie języka (której potrzeba jest faktem bezdyskusyjnym), zaniedbano jednak bardzo istotny element identyfikacji, jakim jest świadomość własnej odrębności - także kulturowej i historycznej, a to ona jest najważniejsza w procesie tożsamościowym" [Jabłoński 2013: 31]. To właśnie poczucie odrębności narodowej da - zdaniem autora - dzieciom motywację do nauki języka kaszubskiego, zaś dorosłym do używania go. Rozwinięta zostaje również wizja apokaliptyczna: bez istnienia kategorii politycznej, wokół której kaszubska tożsamość mogłaby się rozwijać, Kaszubi przestaną istnieć. Jabłoński zabezpiecza się jednak przed zarzutami o tendencje separatystyczne, pisząc, że „narodowość to nic innego, jak poczucie przynależności do konkretnej wspólnoty kulturowej" [lbid.: 33].

Ostatnia część publikacji to postulaty i pomysły konkretnych rozwiązań, które Kaszubi powinni wprowadzić w życie. Dla mnie mniej interesujące są same postulaty, co sposób formułowania tych wypowiedzi, perswazyjny i propagandowy. Wskazują na to następujące zwroty, licznie używane w tekście: „powinny być”, „należy wrócić do koncepcji”, "Musimy natomiast stworzyć ofensywno-konstruktywny wzór zachowań oparty na n i e - 
zaprzeczalnej prawdzie, że jesteśmy odwiecznymi gospodarzami pomorskiej ziemi (...)" [lbid.: 35], "Nie wahajmy się", „Pokażmy” itd. itp. Autor publikacji jest tu liderem, który wskazuje drogę ludziom, przekonuje ich o niepodważalności i słuszności własnej koncepcji (opartej wszak na „niezaprzeczalnej prawdzie”), a także zagrzewa ich do walki stosując krótkie, wykrzyknikowe zwroty. Na końcu wskazuje na zmienność kategorii i proces historyczny tworzenia się i rozwoju narodów (kaszubska wspólnota „d o j r z a † a d o t e g o, by traktować ją tak samo jak inne kultury narodowe" [lbid.: 43]).

Ciekawym zabiegiem jest również nazywanie działaczy KJ „pięknymi dwudziestoletnimi". Samo to określenie (będące chyba mało trafionym nawiązaniem literackim) stanowi część dyskursu narodowościowego: osoby wybierające "kaszubską opcję narodową" to młodzi, idealistyczni, energiczni Kaszubi, wychowani w wolnej Polsce, rozumiejący procesy, które zachodzą i potrafiący z nich korzystać. Są więc opozycją dla "starych" działaczy ZK-P, niezdolnych do nowoczesnego myślenia, zasklepionych w wyznawanych poglądach.

Książeczka Artura Jabłońskiego napisana jest dobrze, czyta się ją łatwo, używane argumenty, formułowane zarzuty pod adresem oponentów, forma, dzięki której czytelnik utożsamia się z autorem („my”) sprawiają wrażenie klarownej i słusznej wizji, spełniają więc wymogi tekstu propagandowego. Publikacja ta, traktowana jako źródło antropologiczne, przynosi bardzo ciekawe informacje. Przede wszystkim wskazuje na rozdział w sposobie formułowania dyskursu kaszubskiego oraz przełamuje istniejący do tej pory monopol działaczy ZK-P, ale - co ciekawe - nie wychodzi z dialogu z ZK-P, prowadząc z nim swoistą walkę o rząd dusz.

\section{3. Źródła medialne}

W przeciwieństwie do sposobu mówienia o narodowości śląskiej, kwestie istnienia kaszubskiej narodowości media przedstawiają zadziwiająco łagodnie, żeby nie powiedzieć wręcz neutralnie. Wynika stąd, że po pierwsze temat ten nie jest traktowany poważnie, po drugie, to nie media (a $w$ każdym razie nie media tradycyjne) tworzą i propagują kaszubski dyskurs narodowościowy, choć oczywiście w pewnym sensie przyczyniają się do upowszechnienia problemu.

$\mathrm{Na}$ potrzeby tego tekstu poddałam analizie koło 20 artykułów prasowych (czyli większość tekstów, które tę kwestię poruszały). Prawie wszystkie ukazały się w prasie lokalnej, jedynie dwa opublikowane zostały przez media o zasięgu krajowym. Podobnie przedstawia się sprawa z audycjami telewizyjnymi i radiowymi. Krótkie programy poświęcone tej kwestii znalazły się w TVN oraz w Teleexpressie, jednak miały one charakter czysto prezentujący. Media lokalne też nie poświęcity wiele miejsca na dyskusję o kaszubskiej narodowości. Temat ten pojawiał się jedynie jako ilustracja działań stowarzyszenia "Kaszëbskô Jednota”. Ten brak zainteresowania świadczy o tym, że kaszubska kwestia narodowa nie jest odbierana jako sensacja, nie jest tematem do dyskusji, jest raczej usuwana z publicznego dyskursu. Także same działania KJ opisywane są w sposób neutralny: prezentowane jest stanowisko "Jednoty", a następnie kontrowane przez działaczy ZK-P. Wydaje się, że przedstawiciele KJ starają się (mają taktykę?), by w mediach przedstawiać kwestię narodowości kaszubskiej w sposób legalistyczny, dowodząc, że wedle prawa polskiego Kaszubi powinni zyskać status mniejszości etnicznej. Przesunięcie następuje więc z dyskusji na temat istnienia (bądź nie istnienia) narodu kaszubskiego, na korzyści, jakie z powodu otrzymania wyższego statusu Kaszubi mogliby zyskać. Typowym przykładem 
sposobu poruszania kaszubskiej kwestii narodowej w prasie jest artykuł "Gazety Wyborczej. Trójmiasto" z dn. 25.01.2012 roku (artykuł Krzysztofa Katki Kaszubska mniejszość wśród Kaszubów): „Jednota dowodzi, że spełniają wszystkie warunki: są mniej liczebni od pozostałej części ludności RP; w sposób istotny odróżniają się językiem, kulturą lub tradycją i dążą, aby je zachować; mają świadomość historycznej wspólnoty etnicznej; ich przodkowie zamieszkiwali obecne terytorium Polski od co najmniej 100 lat". Argumenty wysuwane przez KJ odnoszą się do Ustawy z 2005 roku. Dziennikarz pozwala następnie wypowiedzieć się prezesowi ZK-P: „A właśnie że nie jesteśmy mniejszością etniczną. (...) Państwo kaszubskie nigdy nie istniało, a mniejszość jednak jakoś musi się do niego odnosić. Poza tym jesteśmy ludnością miejscową, od zawsze zamieszkującą Pomorze, a nie grupą, która gdzieś wywędrowała do obcego państwa". W tej ostatniej wypowiedzi słychać echa, typowej dla rozgorączkowanej dysputy między przedstawicielami dwóch opcji, kłótni, w której chodzi o to, żeby oponenta przekrzyczeć, nie zwracając uwagi na merytoryczność używanych argumentów. Wynika z nich bowiem, że naród musi posiadać państwo (a co z narodami bezpaństwowymi?) oraz że pojęcie mniejszości narodowej (etnicznej) dotyczy osób, które „wywędrowały do innego państwa”, zdawałoby się więc imigrantów, o których w Ustawie nie ma ani słowa. W odpowiedzi tej nie chodzi jednak o racjonalne argumenty, a o mocny wydźwięk: mniejszością są ci gorsi, którzy jakoś sobie na to miano zasłużyli (nie chcieli mieszkać w swoim państwie, a więc są wyrzutkami). Tymczasem Kaszubi zawsze byli u siebie, są więc równoprawnymi gospodarzami, a nie jakąś (podejrzaną) mniejszością.

Rzadko w prasie pojawia się otwarta krytyka działań KJ. Przykładem takim jest przywołany wyżej artykuł z "Nordy", w którym krytyka ta wyrażona zostaje nie słowami dziennikarza, a posłanki Doroty Arciszewskiej-Mielewczyk (PiS), zaś całość opatrzona cytowanym już wywiadem z prof. Synakiem. Warto na wypowiedź posłanki zwrócić uwagę, przypomina ona bowiem polityczny dyskurs o Śląsku. Posłanka mówi gazecie: „Działania pana Jabłońskiego są bardzo szkodliwe. A ta komitywa ze Ślązakami stawia nas Kaszubów w niekorzystnym świetle. Przecież Ruch Autonomii Śląska to są separatyści". I dodaje: „Kaszubi są wzorem patriotyzmu! Zawsze przysięgali Bogu i Polsce (...) Takie 'narodowościowe' dzielenie już przynosi szkody. Mam w rodzinie nie-Kaszubów i oni są zniesmaczeni tym, co styszą. Tak samo jak ja" [„Norda”, 3.02.2012]. Słów o Ślązakach nie będę komentować. Charakterystyczna natomiast jest druga część wypowiedzi: to nie-Kaszubi są oburzeni postawą Kaszubów-narodowców. W domyśle: działania na rzecz zaistnienia kaszubskiej opcji narodowej postawią Polaków przeciw Kaszubom i w związku z tym Kaszubów może czekać kara. Jest to więc wypowiedź strachu przed większością, nie zaś troski o swoją grupę.

W nielicznych reportażach telewizyjnych czy radiowych kwestia narodowa przedstawiona jest jako spór: KJ mówi o tym, że Kaszubi są narodem, który był asymilowany, ZK-P twierdzi natomiast, że Kaszubi posiadają (i zawsze posiadali) podwójną polsko-kaszubską tożsamość i proszą działaczy KJ, żeby „pozwolili im być sobą”. Równocześnie podkreślają, że KJ to mała grupka działaczy, w związku z tym w ogóle mówienie o tym problemie wydaje się śmieszne.

Jak wspomniałam na wstępie, kaszubski dyskurs narodowościowy nie jest kształtowany przez media tradycyjne, te bowiem nie przewidują nań miejsca w swoim programie. Jednak w czasach silnej remediacji [Bolter, Grusin 2000], zarówno funkcjonowanie w dzisiejszym świecie prasy, jak i coraz bardziej radia i telewizji, przenosi się do świata cyfrowego. Prasa internetowa daje natomiast czytelnikom nowe możliwości: aktywnego 
komentowania, a więc bycia (do pewnego stopnia) współtwórcami przekazu medialnego. I właśnie dyskusje na forach internetowych pod artykułami dotyczącymi problematyki związanej z istnieniem kaszubskiego narodu, wydają mi się najciekawsze. Już na pierwszy rzut oka ujawnia się podział komentujących na tych, którzy są "za" i tych, którzy są „przeciw” istnieniu narodu. Między obiema stronami dochodzi do typowej kłótni, która kończy się, a nawet zaczyna od rzucania inwektyw pod adresem przeciwników. Czasem jednak pojawia się dyskusja merytoryczna, dzięki której można lepiej przyjrzeć się dyskursowi rządzącemu sprawami narodowościowymi. Chciałabym przeanalizować dwa - jako charakterystyczny przykład - wpisy, które pojawiły się 15.05.2013 roku W „Dzienniku Bałtyckim” pod artykułem „Kaszubi mniejszością narodową? Rząd nie widzi konieczności zmian w ustawie". Pierwsza wypowiedziała się "Zofia":

Jestem Kaszubką z rodziców Kaszubów od wielu pokoleń; jestem Kaszubką mającą takie pochodzenie nie tylko z krwi, ale także z ziemi. Nie mam ochoty być mniejs zością etniczną, czy jakąkolwiek?? Jestem i chcę być pełnoprawną Polką, o co walczyli moi rodzice, nie dając się zniemczyć, mimo nacisków. Czy dla inicjatorów - bycie 'mniejszością' ma być dla nich zaszczytem? honorem? Może można dostać więcej praw niż Polak - Kaszub nie przynależny do 'mniejszości'? Czy może zwyczajnie chodzi o tworzenie nowych 'bytów' [http://www.dziennikbaltycki.pl/artykul/894681,kaszubi-mniejszoscia-narodowarzad-nie-widzi-koniecznosci-zmian-w-ustawie,2,id,t,sa.html].

Ta charakterystyczna wypowiedź porusza dwie istotne sprawy. Pierwsza, o której była już mowa wyżej, dotyczy niechęci Kaszubów do określania ich mianem "mniejszość". Sam termin odbierany jest jako pejoratywny, umniejszający znaczenie danej grupy, odbierający jej przedstawicielom miano bycia pełnoprawnym obywatelem. Po drugie, pokazuje, jak silnie w wyobrażeniu Kaszubów funkcjonuje związek między Polakami a Kaszubami, działającymi razem w opozycji do Niemców. To myślenie wynika z zaborów i germanizacji, a także podziału etnicznego, który na tych pogranicznych terenach oparty był przede wszystkim na wyznaniu: Polacy byli katolikami, Niemcy - protestantami. Kaszubi jako katolicy należeli więc do jednego zbioru z Polakami ${ }^{10}$.

Pod komentarzem „Zofii” pojawiło się kilka ciekawych wpisów, z których zacytuję jeden, autorstwa „Sebastióna”:

(...) Kaszubi nie chcą się tworzyć. Kaszubów nie trzeba tworzyć. Tak jak Pani, ja i wielu innych - my już tutaj jesteśmy od setek lat. Faktem niestety jest, że przez wiele lat napływali na nasze ziemie Polacy, Niemcy, często próbując nas zas y mil o wa ć w taki czy inny sposób i dlatego dzisiaj jesteśmy już tylko obecni na terenie kilkudziesięciu gmin - i to w mniejszości. Jednak żyjąc dzisiaj w granicach państwa polskiego i będąc jego obywatelami, mamy szansę starać się o uzyskanie s t a t u s u pra w n e go.

(...) Jesteśmy pełnoprawnymi obywatelami polskimi narodowości kaszubskiej, nie polskiej.

(...) Czy uważa Pani, że Polacy jako naród istnieliby dzisiaj gdyby podczas rozbiorów dzięki próbom asymilowania zaczęli wołać się 'pełnoprawnymi Rosjanami, czy Niemcami?'. Czy widzi Pani taką możliwość, żeby w niedalekiej przyszłości dzięki licznym napływom Turków do Niemiec Niemcy zdeklarowali się Turkami? [lbid.]

Kaszubi przedstawieni są tu jako autochtoniczny lud zamieszkujący ziemię (w domyśle: stanowiąc formę proto-państwową), na której osiedlali się inni dokonując ich asymilacji i przekonując ich, że nie są odrębnym narodem. Proces ten się udał, czego dowodem są słowa "Zofii", na które „Sebastión" odpowiada. KJ dąży jedynie do nadania Kaszubom,

\section{......}

10 Sytuacja wyglądała inaczej na Śląsku, o czym pisze Grażyna Kubica [2011]. 
będącym narodem, legalnego statusu. Sytuacja Kaszubów nie różni się niczym od sytuacji narodów uznanych, na których terytorium sprowadzają się osoby z zewnątrz, przejmując stopniowo władzę i asymilując autochtonów. Kaszubi są więc narodem skolonizowanym, a niechęć do uznania się za odrębny od polskiego naród jest typowym zachowaniem ludów postkolonialnych, które po latach ucisku przyjmują system aksjologiczny i sposób myślenia uciskających [por. Colonial Discourse 1994].

"Sebastión” więc dzieli Kaszubów na „dobrych” i „złych”: tych, dla których kaszubskość nie jest dziś ważna, gdyż ulegli asymilacji (z czego nie zdają sobie już sprawy) i uważają się za Polaków, oraz tych, którzy walczą o przetrwanie Kaszubów. W wypowiedziach dowodzących istnienia kaszubskiego narodu, granica etniczna [por. Barth 2004] ukazana jest jako bardzo ostra. Bycie Kaszubem wyklucza bycie Polakiem (w rozumieniu etnicznym, nie obywatelskim). Takie postawienie kwestii kaszubskiej jest jednak sprzeczne z odczuciami większości Kaszubów, którzy czują się przez działaczy KJ manipulowanymi. Dlatego warto przeanalizować dyskurs młodych, zaangażowanych Kaszubów, pochodzących z dwóch przeciwnych obozów, obozu KJ i obozu KS „Pomorania”, żeby zobaczyć, w jaki sposób dyskusje prowadzone w środowiskach kaszubskich wpływają na młodych ludzi oraz jaki oni sami mają na te dyskusje wpływ.

\section{WYWIADY Z MŁODYMI ZAANGAŻOWANYMI KASZUBAMI}

Anthony D. Smith twierdzi, że rdzeń etniczności mieści się w tworzonych przez społeczność „mitach, wspomnieniach, wartościach, symbolach" [Smith 2009: 19]. Młodzi Kaszubi z KJ, „piękni dwudziestoletni”, w rozmowie ze mną często opowiadają o kaszubskiej historii, tworzą i odtwarzają mit założycielski państwa kaszubskiego. Powoływanie się na "obiektywne" przesłanki istnienia narodu kaszubskiego nadaje ich wyborom niepodważalne znaczenie. Na moje pytanie, co to znaczy dla A. być Kaszubem, usłyszałam następującą odpowiedź:

A20M"11: [Być Kaszubem] to znaczy być spadkobiercą całego dziedzictwa Stowian Nadbaltyckich, których jesteśmy obecnie jedynymi spadkobiercami. Być Kaszubem to jest być naprawdę wielkim szczęściarzem, bo przez tyle setek lat myśmy nie mieli żadnej organizacji, państwowej ani żadnej innej, a mimo to nasz język jakimś cudem przetrwał. (...)

Chłopak wywodzi swoją tożsamość z odległych "mitycznych” czasów, podkreślając, że w związku z pochodzeniem zapewniającym wyjątkowość Kaszubów, spoczywa też na nich wielka odpowiedzialność za przyszłość wspólnoty.

Do kwestii istnienia kaszubskiego państwa wróciliśmy w rozmowie. A. opowiadał o tym, jak zaczął rozmyślać na temat swojej kaszubskiej przynależności i dlaczego w ruch narodowościowy się zaangażowat:

A20M: Początkowo ja sam nie chciałem tego do siebie przyjąć [że Kaszubi są odrębnym narodem], bo to jakoś burzyło to, kim jestem. Bo zawsze byłem Polakiem, zawsze mnie uczono, że jestem Polakiem, że tutaj zawsze była Polska itd. Ale być może przez to przesycenie tą polskością w momencie, kiedy ja zrozumiałem, że myśmy kiedyś mieli nawet własne państwo, że nasz język przetrwał, bo myśmy się przed Piastami bronili w średniowieczu iże później teżczasy międzywojenne wca-

11 A - nadany przeze mnie symbol osoby, 20 - wiek osoby, M - mężczyzna (K - kobieta). 
Ie nie byty takie różowe dla relacji polsko-kaszubskich, ja się w tym momencie poczułem oszukany i to chyba musiała być taka odskocznia od tego. Tak początkowo chyba było.

To stopniowe dochodzenie do świadomości etnicznej, zapoczątkowane usłyszanymi przypadkowo hasłami narodowymi, następnie pogłębione przez lektury i wiedzę historyczną, w połączeniu z kaszubocentryczną interpretacją wydarzeń, doprowadziło do podjęcia świadomej decyzji, by mówić i myśleć o sobie jako o Kaszubie, który mieszka w Polsce, jednak etnicznie przynależy do odrębnej grupy.

Ze stawiania ostrej granicy etnicznej między Kaszubami a Polakami, zwłaszcza przez młodych ludzi, którzy potrzebują jasnych sytuacji i z braku doświadczenia w sposób prostolinijny kategoryzują świat, wynika często zacietrzewienie Kaszubów-narodowców, którzy potrafią o Polsce i polskości wypowiadać się w sposób krytyczny. To najbardziej boli młodzież zgrupowaną W KS „Pomorania”. Wielokrotnie osoby te podkreślały swoją podwójną, kaszubsko-polską tożsamość, mówiąc o tym, że tego nigdy nie dzieliłam, nie rozróżniałam (I22K). Tym bardziej bolą je słowa krytyczne wobec własnej identyfikacji. Stąd wynika w dużej mierze złość na KJ i jej młodych działaczy, którym przypisuje się najgorsze cechy, próżność, chamstwo, niemalże zdradę ojczyzny:

M22K: (...) Denerwuje mnie to, że oni nie chcą się przyznawać, że mają coś wspólnego z Polską. Bo jednak urodzili się tutaj, żyją tutaj, pracują tutaj, żywi ich polskie państwo. Ajednaknie chcą mieć z tą Polską nic wspólneg o. To zrób sobie kaszubskie poletko i sam je uprawiaj i niech cię żywi, zobaczymy jak ci pójdzie. Bez Polski po prostu nie ma Kaszub. Dla mnie to jest pewien rodzaj hipokryzji. Odcinanie się od tego grubą krechą. (...) Dla mnie takie przekonania ludzi są po prostu nie do zaakceptowania. Są to postawy nie przemyślane do końca. Bo jednak jest to ostra opozycja dla Kaszuby, który jest Kaszubą i Polakiem.

Wypowiedź ta, choć bardzo ostra, jest jednocześnie charakterystyczna. Kaszubi, którzy przyjmują narodowość kaszubską, nie tylko nie chcą być Polakami, ale oskarżani są, że nie chcą mieć z Polską "nic wspólnego”. Skoro nie identyfikują się (etnicznie) jako Polacy (i Kaszubi), nie powinni korzystać z dóbr, które mają dzięki państwu, na którego terytorium zamieszkują. Echa dyskursu ksenofobicznego są w tej wypowiedzi bardzo silne, choć sądzę, że intencją studentki była krytyka nie mniejszości jako takich, a jedynie tych Kaszubów, którzy dążą do podziału etnicznego. Niemniej wypowiedź taka w ustach przedstawiciela bądź co bądź grupy nieuprzywilejowanej (celowo unikając określenia Kaszubów mniejszością) może co najmniej dziwić. Jak stosunek do Polski przedstawiany jest więc przez mtodych z KJ?:

J21M: My jednak jednomyślnie u z naje my Polskę za kraj Kaszubów, bojedn a k Kaszubi przez wiele lat za Polskę walczyli i oddawali swoje życie. Ale uznajemy, że możemy być w tym kraju odrębnym narodem i mamy pełne prawa do autonomicznego rozwoju naszej kultury i naszej świadomości. Nie jest to taka autonomia, o którą walczą Ślązacy i którą kiedyś tam mieli w latach 20., bo nie o to chodzi. A le tu chodzi przede wszyst kim o zachowanie jak największejodrębności kulturowej, dla zachowania tego dla następnych pokoleń.

A20M: (...) Rzeczpospolita Polska jest naszym krajem, my broń Boże nie chcemy się oderwać od tego kraju, nasi dziadkowie walczyli za ten kraj. I w związku z tym_chcielibyśmy, żeby nasz naród był uszanowany i uznany w polskim prawi e. Jeśli to będzie ukonstytuowane, że Kaszubi też są narodem, wówczas też my możemy zupełnie swobodnie i zupełnie szczerze powiedzieć, że Polska jest naszym krajem, że jesteśmy jego częścią. 
Wypowiedzi te są ciekawe nie tylko dlatego, że całkowicie przeciwstawiają się opiniom wygłaszanym przez studentów z KS „Pomorania”. Młodzi działacze KJ powtarzają hasła polityczne przyjęte przez swoje stowarzyszenie za obowiązujące. Ze słów młodych wynika jednoznacznie, że chcą oni uznania prawa Kaszubów do miana narodu, zagwarantowania im ochrony prawnej w ramach demokratycznego państwa, którego obywatelami się czują. Dlaczego więc taki dysonans? Z jednej strony wynikać to może z różnicy w tonie wypowiedzi kierowanej do badaczki z zewnątrz, a tym, który utrzymywany jest w relacjach z młodymi z własnego otoczenia. Z drugiej strony sądzę, że wynika on z tego, że młodzi z KJ uderzają w najczulszy punkt Pomorańców, którzy zostali wychowani w poczuciu, że Kaszubi są Polakami, a związek ten potwierdzony został niejednokrotnie przez wspólną walkę i cierpienie. Właśnie ta wspólnota losów i działań mieści się w ich pamięci kulturowej, która mówiąc za Assmannem gromadzi przeszłość oddaloną od dnia codziennego, opartą na wydarzeniach rozstrzygających o losie narodu czy grupy [Assmann 2008: 66-71]. Kaszubscy narodowcy gwałcą więc podstawy ich tożsamości i pojmowania otaczającego świata. Tymczasem przedstawiciele KJ uważają, że postawa polonocentryczna Kaszubów wiąże się z asymilacją kulturową, jaka się dokonała, a także z - wynikającego częściowo z niej - kompleksu kaszubskiego, który jest formą tożsamości negatywnej. Młodzi działacze KJ, z którymi rozmawiałam, nauczyli się języka kaszubskiego sami lub na kursach i przy pomocy przyjaciół. Jednak dokonali świadomego wyboru, by językiem kaszubskim się posługiwać publicznie, uczynili wręcz z tego manifestację swojej tożsamości. Mają za złe studentom z KS „Pomorania”, że języka kaszubskiego nie używają bądź używają sporadycznie, przy okazji uroczystości, nie traktują natomiast tego języka jako równorzędnego z polskim:

A20M: Najbardziej mnie denerwuje takie zakompleksienie Kaszubów, którzy (...) wygłaszają piękne przemówienie po kaszubsku o tym, jak to ich dziadkowie mieli ciężko, rodzice mieli ciężko, a my możemy wreszcie nieskrępowanie mówić po kaszubsku i jest tak fajnie i mamy tak dobrze. A potem ja podchodzę do tej osoby i mówię do niej po kaszubsku, a ona mówi: 'weź się nie wydurniaj, dlaczego mówisz po kaszubsku? Możemy n o r m a I n i e mówić.' No to mnie denerwuje taka hipokryzja i zakompleksienie. A ja właśnie chcę pokazywać, że oprócz tych przemówień i super inicjatyw można być Kaszubą na co dzień.

Wypowiedź ta nie jest tylko krytyką spolonizowanych Kaszubów. Młody człowiek wyraźnie kategoryzuje Kaszubów na tych „prawdziwych” i tych, którzy kaszubskość tylko udają, pokazują ją, ale nie chcą po kaszubsku mówić na co dzień. Dla "spolonizowanych" Kaszubów mówić "normalnie” to mówić po polsku - to jest pierwszy język większości przedstawicieli kaszubskiego młodego pokolenia, z nim się identyfikują. Dopóki kaszubska identyfikacja nie zostanie zinternalizowana, zaś język kaszubski nie zostanie wtórnie i świadomie wyznaczony na język pierwszy (czy raczej język używany rozmyślnie w każdej możliwej sytuacji życiowej), dopóty „normalnym” językiem będzie polski, zaś podstawą identyfikacji przynależność do narodu polskiego. Co ciekawe, zarzuty tej samej natury Pomorańcy stawiają działaczom KJ:

I22K: I też uważam, że kilka razy spotkałam się z takimi Kaszubami, którzy dla mnie byli s ztu czni. Poprzez akcentowanie swojej kaszubskości chcieli tylko coś ugrać, a tak naprawdę jakoś tak emocjonalnie nie czują się z tym tak związani. I wtedy też robiło mi się nieswojo, bo dla mnie ten kaszubski jest taki prawdziwy i to jest taka miłość wielka, a tutaj tylko ktoś chce na tym zyskać pod względem finansowym na przykład.

W oczach osób, które wychowały się w kaszubskich wioskach i tożsamość kaszubską odczuwają tak, jak przekazali im to rodzice i dziadkowie, z całym bagażem kompleksów, 
uprzedzeń i strachu przed wykluczeniem, działacze KJ są „sztuczni”, działają nie z potrzeby serca, lecz chęci zyskania rozgłosu, pozycji czy pieniędzy. Kaszubskość reprezentowana przez nich jest im bowiem obca, jest innym typem etnicznej przynależności niż ten, który wynieśli z własnych rodzin. Kontakt z inną kulturą - gdyż wydaje mi się, że kaszubska kultura ma w tej chwili wiele obliczy i każda z dwóch grup mówi o innym typie kaszubskiej kultury - powoduje konieczność podkreślania, że tylko jedna z tych opcji może być słuszna:

I22K: (...) Ja nie wiem, dlaczego niektórzy tak bardzo chcą być odrębni od reszty kraju, dlaczego oni uważają, że krzywdę im się zrobiło, że mają mi eć obywatelstwo polskie, a nie kaszubskie, że uważają, że to powinny być osobne narody. Dla mnie ja tego nigdy nie rozróżniałam, nie dzieliłam. I też przyglądając się historii Kaszubów od XVIII wieku, nigdy nie było tak, że oni się czuli kimś innym. Byli Kaszubami, mówili po kaszubsku, choć pewnie nie do końca zdawali sobie sprawę z tego, że mówią w innym języku niż polski. Ale jednak to zawsze była Polska. I teraz te głosy, które się pojawiają, że Polska nas skrzywdzita i nas wchtonęta to dla mnie to też jest na siłę. Na siłe głoszenie haset rewolucyjnych. To jest robienie mętliku w głowach ludzi, nawet nie Kaszubów, ale np. Polaków mieszkających w innej części kraju. (...)

Trzy elementy tej wypowiedzi mają duże znaczenie dla naszej analizy. Po pierwsze, działacze KS „Pomorania” również starają się historycznie dowieść polsko-kaszubskiej wspólnoty i zobiektywizować własną identyfikację. Druga kwestia dotyczy nomenklatury. Obywatelstwo nie wiąże się z narodowością, a z prawami jednostki przyznawanymi przez państwo, na którego terenie dany człowiek zamieszkuje. Przedstawiciele mniejszości zamieszkujących w Polsce, niezależnie od odczuwanej przez nich tożsamości narodowej czy etnicznej, są polskimi obywatelami. Z ciągłego mieszania kluczowych dla kwestii etnicznych pojęć (takich jak autonomia, separatyzm, narodowość, obywatelstwo, mniejszość) wynika, że Kaszubi nie zostali w żaden sposób na dyskusję, która się wokół nich rozgrywa, przygotowani. Pojęcia te znają jedynie z przekazu medialnego, z pojedynczych urwanych wypowiedzi polityków czy działaczy. Nie rozumieją jednak i nie odczuwają różnic, intuicyjnie (a intuicja ta została stworzona m.in. przez szowinistyczny dyskurs niektórych polityków i mediów) czując, że wszystkie te pojęcia są niebezpieczne:

B24K.: Właśnie przez tę dyskusję było strasznie dużo szumu i to takiego negatywnego. Jakoś ja się od tego całkowicie odcinam, a jak słysze o takich rzeczach jak autonomia Kaszub, to coś aż normalnie... No nie podoba mi się to. Zwłaszcza że potem osoby spoza też tak reagują: a bo ty jesteś z Kaszub, wy chcecie mieć a utonomie i wogóle. (...) nigdy takie separowanie się, podkreślanie swojej odrębności na zewnątrz nie było dobrze odbierane. W żadnym przypadku. Więc to wpływa niezbyt pozytywnie na wizerunek Kaszubów.

Z obu powyższych wypowiedzi wypływa jeszcze jeden, trzeci wniosek: mówienie o kaszubskich kwestiach narodowych odczuwane jest jako zagrożenie, gdyż może być negatywnie odbierane przez Polaków i wpływać na ich postawy wobec Kaszubów. Młodzi tłumaczą sobie jednak, że ich koncepcja kaszubskiej etniczności łączy się z postawą otwartości na inne kultury:

M22K.: Mamy określony pogląd na kaszubskość i wiemy, czego byśmy chcieli uniknąć. Nie pociągają nas decyzje separatystyczne Kaszubów. Nasz klub nie był zaangażowany politycznie. Chcemy pielęgnować to, co było, bo jest to wartościowa spuścizna po poprzednikach, ale chcemy też rozwijać się na całą Europę, a nie zamykać się na to, że jesteśmy Kaszubami i tylko Kaszubami, ale chcemy też poznawać innych, chcemy, żeby nas poznano i na tej zasadzie my działaliśmy i chcemy nadal działać. Bo nie chodzi o to, żeby się zamknąć, ale żeby się otworzyć. 
"Zamykają się", zdaniem Pomorańców, działacze KJ: jednoznaczny wybór kaszubskiej opcji narodowej musi się, w ich oczach, wiązać z ograniczeniem. Tymczasem zupełnie inaczej swoją kaszubskość pojmują młodzi narodowcy. Dla nich jest ona świadomym wyborem, ale takim, który wyzwolit ich „prawdziwą", ukrytą przez lata asymilacji naturę:

A20M.: Więc to jest na pewno kwestia świadomego wyboru, ale ja ten wybór uznaję za naturalną drogę dla mnie. Jakakolwiek inna opcja byłaby jakimś wynaturzeniem. Bo kiedy mówię po kaszubsku, choć może kiedyś w dzieciństwie nie mówiłem, to jest coś zupełnie naturalnego, to jest przerwanie czegoś, co było nienaturalne, czyli narzucenia obcej kultury. A teraz to jest powrót do tej naturalności czyli to jest jakby zupełnie coś normalnego, że jestem Kaszubem i chciałbym tym zarażać innych i pokazywać, że Kaszubem można być normalnie.

Młodzi działacze KS „Pomorania” uważają, że młodzi z KJ uwierzyli w podaną im ideologię i stali się jej zagorzałymi wyznawcami. Za ich kaszubskością nie stoi jednak „kaszubski duch" (to charakterystyczne określenie pada w wielu wywiadach), a potrzeba zaistnienia publicznego. Z kolei młodzi z KJ zarzucają Pomorańcom, że nie dostrzegają, jak daleko posunęła się ich polonizacja i dlatego uważają, że Kaszubi nie są odrębnym narodem. Nie jest to więc już tylko spór o termin "naród” traktowany ideologicznie, politycznie czy kulturowo. Chodzi tu o koncepcje przynależności etnicznej i ich skutków dla dalszych losów Kaszubów. Obie opcje postępują według swojego odczucia najlepiej i zgodnie z własną tożsamością: obrońcy opcji kaszubsko-polskiej uważają, że narzucanie Kaszubom etykietki "narodu" jest sprzeczne z ich odczuwaniem rzeczywistości i ich własną identyfikacją, na dodatek nie przyniesie im korzyści, może natomiast zaszkodzić. Ideolodzy opcji narodowej twierdzą natomiast, że bez tworzenia nowych struktur, umacniania poczucia odrębności kulturowej, kaszubskość już wkrótce rozmyje się całkowicie w polskości, a wtedy na działania będzie już za późno.

Tożsamość kulturowa nie jest zastygła, znajduje się w ciągłym ruchu, zmienia się pod wpływem wydarzeń i procesów, jakie na daną grupę oddziałują. Jest nieustannie negocjowana i rekonstruowana na różne sposoby. Kaszubska tożsamość również jest płynna. W ciągu ostatnich kilkunastu lat zaczęła być definiowana i potwierdzana w całkowicie nowy sposób, jako wartość pozytywna, a nie balast, który dla własnego dobra lepiej odrzucić. Liczne działania i projekty, którymi Kaszuby zostały objęte, mają na celu utwierdzenie kaszubskiej wspólnoty i wymazanie ciążącego nań kaszubskiego kompleksu. Jest to proces bardzo trudny i wcale nie koniecznie skazany na powodzenie. Pojawienie się kaszubskiej opcji narodowej może być na tle tych przemian społeczno-kulturowych rozpatrywane jako konsekwencja wydarzeń ostatnich lat, konsekwencja powolnego procesu zyskiwania świadomości wartości własnej kultury. Kaszubska tożsamość ulega w tej chwili zmianie, o czym w sposób dobitny świadczą burzliwe dyskusje dotyczące kaszubskiej narodowości.

Kwestia kaszubskiej narodowości jest w tej chwili jednym z najistotniejszych tematów dla kaszubskich elit. Każda osoba, która jakoś w kaszubskość się obecnie angażuje, postawiona jest niemal przed koniecznością dokonania wyboru: jakim Kaszubem się jest i jakim chce się być. Każde ze środowisk stara się, żeby ich idee i poglądy przedstawić w jak najbardziej przyjazny sposób, by przyciągnęły kolejnych zainteresowanych. Ta rywalizacja bywa jednak odbierana niekiedy jako uciążliwa. Tak wypowiedział się o niej działacz KS „Pomorania", który jednak przyznał, że jego rodzina nie jest kaszubska, gdyż w ich domu po kaszubsku się nie rozmawiało, mimo że prawie wszyscy członkowie rodziny zaangażowani są w działania na rzecz lokalnej wspólnoty (kulturalne i polityczne): 
N22M.: Walka o świadomość, tożsamość drugiego człowieka, każdego z nas. Walka o twoje myślenie na temat kaszubskości. Taka trochę brzydka batalia o to, kto tak naprawdę jest lepszym Kaszubem, kto lepiej rozpatruje przyszłość ruchu kaszubskiego. Ukierunkowywanie drugiego człowieka, jak ma myśleć, a nie pozostawienie takiego myślenia, jakie mamy. (...) na współczesnych Kaszubach nie podoba mi się taka ciągłą dyskusja o tożsamości: że ty nie możesz być i Kaszubem i Polakiem, że nie można być rozdwojonym.

Nawet w tej wypowiedzi słychać zarzut pod adresem KJ, która zaczęła dyskusję o kaszubskiej narodowości. Tożsamość, świadomość etniczna, przynależność do wspólnoty, połączona z tym odpowiedzialność za przyszłość mniejszości - to są kwestie, które w dzisiejszym świecie rozpatrywane są indywidualnie. Jednak nigdy ten indywidualny osąd nie istnieje w oderwaniu od kontekstu. Na sposób definiowania się młodych wpływ ma zarówno rodzina, otoczenie, szkoła, nauczyciele, animatorzy kultury, z którymi się zetknęli, jak i medialny przekaz. Z wywiadów, które prowadziłam w 2012 roku na Kaszubach wynika, że dla młodych ludzi niebagatelne znaczenie ma to, do którego środowiska („subkultury" kaszubskiej) się trafi. Rozmowy z bardziej doświadczonymi kolegami, ich działania, polecane przez nich lektury i ich interpretacje, są istotną inspiracją własnych działań i decyzji tożsamościowych.

\section{PODSUMOWANIE}

Ostatnie lata przyniosły Kaszubom wiele zmian: kaszubski ze zdegradowanego dialektu języka polskiego stał się językiem regionalnym, kultura istniejąca w czasach komunizmu głównie pod postacią folkloru rozkwitła i rozwija się. Kaszubi biorą udział w lokalnym życiu politycznym, nauczyli się też walczyć o uznanie swoich praw na arenie ogólnopaństwowej. Wszystkie organizowane działania wokół kaszubskiej kultury i języka wzmacniają kaszubską tożsamość i poczucie wspólnotowości. Jednocześnie jednak przekaz międzypokoleniowy języka kaszubskiego został bardzo osłabiony, młode pokolenia rzadko uczy się kaszubskiego w domu. Coraz silniej przynależność do kaszubskiej wspólnoty opiera się na indywidualnej decyzji i chęci włączenia się w lokalne życie niż na więzach krwi i pochodzeniu. Dlatego też znaczenia nabierają działania służące budowaniu kaszubskiej wspólnoty wyobrażonej, dzięki której ich specyfika nie zatopi się w morzu kultury polskiej i globalnej. Otwartym pytaniem pozostaje, jakie działania powinny być podejmowane, by tak się nie stało. Odpowiedź starają się dać zarówno ci, którzy nie chcą zmiany w istniejącym statusie Kaszubów, którzy dowodzą, że nazywanie Kaszubów odrębnym od polskiego narodem jest niezgodne z samoidentyfikacją większości z nich, co więcej, mogłoby przynieść Kaszubom szkodę, gdyż sprowadziłoby na nich niechęć Polaków. Nie biorą oni jednak pod uwagę tego, że tożsamość kaszubska cały czas ewoluuje, zmienia się, przekształca i może się okazać, że z kulturą, która nie chce się odróżniać od państwowej niewiele osób się identyfikuje. Z drugiej strony pada stanowcza deklaracja, że Kaszubi są odrębnym narodem i ich status powinien być prawnie zmieniony. Postawienie kwestii narodu na ostrzu noża prowadzi do niechęci wielu osób, obawy o intencje działaczy i konsekwencje, które mogłyby Kaszubom grozić. Analizując różne typy źródet, widać, że Kaszubi zostali pchnięci w poważną dyskusję, do której nie są jeszcze przygotowani, a która będzie miała realny wpływ na sposób odczuwania kaszubskiej tożsamości przez następne pokolenia. Czy dyskusja wokół kaszubskiej narodowości się rozwinie, czy przycichnie, zależeć będzie w dużej mierze od determinacji niewielkiej grupy Kaszubów - narodowców i tego, jak głośno i wytrwale będą chcieli się w to angażować. 
Adamczuk L., Łodziński S. (red.), 2006, Mniejszości narodowe w Polsce w świetle Narodowego Spisu Powszechnego z 2002 roku, Warszawa: Wydawnictwo Naukowe Scholar.

Anderson B., 1997, Wspólnoty wyobrażone. Rozważania o źródłach i rozprzestrzenianiu sie nacjonalizmu, tłum. Stefan Amsterdamski, Kraków-Warszawa: Wydawnictwo "Znak", Fundacja im. Stefana Batorego.

Assmann J., 2008, Pamięć kulturowa. Pismo, zapamiętywanie i polityczna tożsamość w cywilizacjach starożytnych, przeł. A. Kryczyńska-Pham, Warszawa: Wydawnictwa Uniwersytetu Warszawskiego.

Barker F., Hulme P., Iverson M. (red.), 1994, Colonial Discourse/Postcolonial Theory (Essex Symposia), Manchester: Manchester University Press.

Barth F., 2004, Grupy i granice etniczne: społeczna organizacja różnic kulturowych, przet. M. Głowacka-Grajper, w: Badanie kultury. Elementy teorii antropologicznej. Kontynuacje, red. M. Kempny, E. Nowicka, Warszawa: Państwowe Wydawnictwo Naukowe.

Blommaert J., 2005, Discourse: Key Topics in Sociolinguistics, Cambridge: Cambridge University Press.

Bolter J., Grusin R., 2000, Remediation. Understanding New Media, Cambridge-London: MIT Press.

Burszta W., Jaskułowski K, 2005, Mniejszości narodowe i etniczne a idea państwa narodowego na początku XXI wieku, w: Polityka państwa polskiego wobec mniejszości narodowych i etnicznych, red. L. Nijakowski, Warszawa: Wydawnictwo Sejmowe.

Colonial discourse and post-colonial theory. A reader, 1994, red. P. Williams, L. Chrisman, New York: Columbia University Press.

Dołowy N., 2008, Kaszubi - naród, mniejszość, grupa posługująca się językiem regionalnym, „Przegląd Humanistyczny” 6, 73-94.

Dołowy-Rybińska N., 2011, Języki i kultury mniejszościowe w Europie: Bretończycy, Łużyczanie, Kaszubi, Warszawa: Wydawnictwa Uniwersytetu Warszawskiego.

Hastrup K., 2008, Droga do antropologii. Między doświadczeniem a teorią, przet. Ewa Klekot, Kraków: Wydawnictwo Uniwersytetu Jagiellońskiego.

Hobsbawm E., 2008, Wprowadzenie. Wynajdywanie tradycji, w: Tradycja wynaleziona, red. E. Hobsbawm, T. Ranger, przeł. M. Godyń i F. Godyń, Kraków: Wydawnictwo Uniwersytetu Jagiellońskiego.

Howarth D., 2008, Dyskurs, przeł. A. Gąsior-Niemiec, Warszawa: Oficyna Naukowa.

Jabłoński A., 2013, Kaszubi. Wspólnota narodowa, Gdynia: Region.

Jaskułowski K., 2009, Nacjonalizm bez narodów. Nacjonalizm w koncepcjach anglosaskich nauk społecznych, Wrocław: Wydawnictwo Uniwersytetu Wrocławskiego.

Jawor A., 2009, Apokalipsa Samuela Huntingtona?, "Sprawy Narodowościowe - Seria nowa" 34, s. 207-216.

Kawka M., 2011, O pomnikach i statuach w macedońskim dyskursie parlamentarnym, w: Macedoński dyskurs niepodległościowy: historia, kultura, literatura, język, media, red. i Stawowy-Kawka, M. Kawka, Kraków: Wydawnictwo Uniwersytetu Jagiellońskiego.

Kubica G., 2011, Śląskość i protestantyzm. Antropologiczne studia o Śląsku Cieszyńskim, proza i fotografia, Kraków: Wydawnictwo Uniwersytetu Jagiellońskiego.

Łodziński S., 2007, Między grupą etniczną a społecznością posługującą się językiem regionalnym. Ewolucja statusu prawnego Kaszubów w polityce państwa w Polsce po 1989 
roku, w: Kim są Kaszubi? Nowe tendencje w badaniach społecznych, red. C. ObrachtProndzyński, Gdańsk: Instytut Kaszubski.

Majewicz A., Wicherkiewicz T., 2001, Polityka językowa na Kaszubach na tle prawodawstwa wobec mniejszości w jednoczącej się Europie (Diagnoza i postulaty), w: Kaszubszczyzna/Kaszëbizna, red. E. Breza, Opole: Uniwersytet Opolski - Instytut Filologii Polskiej, s. 81-98.

Nijakowski L., 2002, Dyskursy o Śląsku: kształtowanie śląskiej tożsamości regionalnej i narodowej w dyskursie publicznym, Opole: Wydawnictwo Uniwersytetu Opolskiego.

—, (red.), 2004a, Nadciągają Ślązacy. Czy istnieje narodowość śląska?, red. L. Nijakowski, Warszawa: Wydawnictwo Naukowe Scholar.

—, 2004b, O procesach narodotwórczych na Śląsku, w: Nadciągają Ślązacy. Czy istnieje narodowość śląska?, red. L. Nijakowski, Warszawa: Wydawnictwo Naukowe Scholar.

Nowicka E., 2007, Stara i nowa kaszubskość. Kaszubskość jako etniczność i jako regionalizm, w: Kim są Kaszubi? Nowe tendencje w badaniach społecznych, red. C. ObrachtProndzyński, Gdańsk: Instytut Kaszubski.

—, 2009, Kulturowa odmienność w działaniu. Narody duże i małe, stare i młode, w: Kulturowa odmienność w działaniu. Kultury i narody bez państwa, red. E. Nowicka, Kraków: Nomos.

Obracht-Prondzyński C., 2002, Kaszubi. Między dyskryminacją a regionalną podmiotowością, Gdańsk: Instytut Kaszubski w Gdańsku, Instytut Filozofii i Socjologii Uniwersytetu Gdańskiego.

-, 2006, Spisy czy spiski, czyli o problemach z liczeniem Kaszubów, w: Mniejszości narodowe w Polsce w świetle Narodowego Spisu Powszechnego z 2002 roku, red. L. Adamczuk, S. Łodziński, Warszawa: Wydawnictwo naukowe Scholar.

—, 2009, Kaszubi - naród "niereprezentowany", czy reprezentowany "nie-naród"?, w: Kulturowa odmienność w działaniu. Kultury i narody bez państwa, red. E. Nowicka, Kraków: Nomos.

Ossowski S., 1967, Zagadnienie więzi regionalnej i więzi narodowej na Śląsku Opolskim, Dzieła t. III, Warszawa: PWN.

Pasieka A., (w druku), Wielokulturowość po polsku. O polityce wielokulturowości jako mechanizmie umacniania polskości, "Kultura i Społeczeństwo".

Sekuła E., 2009, Po co Ślązakom potrzebny jest naród? Niebezpieczne związki między autonomią i nacjonalizmem, Warszawa: Wydawnictwa Akademickie i Profesjonalne.

Skutnabb-Kangas T., 2000, Linguistic Genocide in Education - Or Worldwide Diversity and Human Rights?, London: Lawrence Erlbaum Associated.

Smith A., 1991, National Identity, London: Penguin Book of London.

—, 2009, Etniczne źródła narodów, przeł. M. Głowacka-Grajper, Kraków: Wydawnictwo Uniwersytetu Jagiellońskiego.

Synak B., 1991, Tożsamość kulturowo-etniczna Kaszubów a idea krajowości (regionalizmu), „Kultura i Społeczeństwo" 2, s. 82-86.

Znaniecki F., 1990, Współczesne narody, Warszawa: Państwowe Wydawnictwo Naukowe. —, 1973, Socjologia wychowania, t. 2., Warszawa: Państwowe Wydawnictwo Naukowe.

http://www.spis.kaszubi.pl/.

http://sejmometr.pl/legislacja_projekty_ustaw/301

http://www.dziennikbaltycki.pl/artykul/894681,kaszubi-mniejszoscia-narodowa-rzad-niewidzi-koniecznosci-zmian-w-ustawie,2,id,t,sa.html 
https://mail.google.com/mail/u/0/?shva=1\#inbox/13f8a5900a2441b8

"Norda. Tygodnik Kartuzy", Krzysztof Miśdzioł, Roman Kościelniak, Burza w szklance wody?, 2.03.2013.

"Gazeta Wyborcza. Trójmiasto", Krzysztof Katka, Kaszubska mniejszość wśród Kaszubów, 25.01.2012.

\section{KASHUBIAN NATIONAL DISCOURSE - AN ANTHROPOLOGICAL VIEWPOINT}

\section{Summary}

An animated discussion concerning the status of the Kashubs is at present ongoing in Kashubia. In 2005, the Act on National and Ethnic Minorities and the Regional Language was passed in Poland and Kashubian gained the status of a regional language within Poland but Kashubs were not recognized as a distinct group. Following the 2011 Census, the Association of People of Kashubian Nationality, Kaszëbskô Jednota, was created. The Association considers Kashubs to be a nation and is striving to change the Kashub status to that of an ethnic minority. The Kashubian-Pomeranian Association which until now was the only institutional representative of Kashubs does not recognize the Kaszëbskô Jednota aspirations and they consider that Kashubs have a double Polish and Kashubian identity. Both organizations are trying to convince as many people as possible to support their arguments. Meanwhile in Kashubia there are numerous cultural and political movements which influence the Kashubian identity. This article is an analysis of the Kashubian national discourse based on socio-scientific texts and Kaszëbskô Jednota information documents, media sources and interviews with young Kashubs engaged in the movement. This analysis confirms that the Kashubian identity is changing and the discussions underline different perceptions of the role which Kashubs should have in Poland.

Keywords: Kashubian, national discourse, anthropological viewpoint 